\title{
Synthesis and Biological Evaluation of Indoloquinolines and Pyridocarbazoles: A New Example of Unexpected Photoreduction Accompanying Photocyclization
}

\author{
Pierre-Jean Aragon, ${ }^{a, b}$ Ange-Désiré YaPI,${ }^{c}$ Frédéric Pinguet,${ }^{b}$ Jean-Michel Chezal, ${ }^{d}$ \\ Jean-Claude Teulade, ${ }^{d}$ and Yves BlaChE ${ }^{*, c}$ \\ ${ }^{a}$ Laboratoire de Chimie Organique Pharmaceutique, E.A. 2414, Faculté de Pharmacie; 15 avenue Charles Flahault, \\ 34060 Montpellier, France: ${ }^{b}$ Laboratoire d'Oncopharmacologie, Centre Régional de Lutte Contre le Cancer; Val \\ d'Aurelle, 34298 Montpellier cedex 05, France: ${ }^{c}$ Laboratoire de Chimie Organique Pharmaceutique, UMR-INSERM 484, \\ Faculté de Pharmacie; 28 Place Henry Dunant, B.P. 38, 63001 Clermont-Ferrand, France: and ${ }^{d}$ Laboratoire de Chimie \\ Organique, EA 3660, Faculté de Pharmacie; 7 Boulevard Jeanne d'Arc, 21079 Dijon, France. \\ Received May 23, 2007; accepted June 28, 2007
}

\begin{abstract}
Indoloquinoline alkaloid cryptolepine and pyridocarbazole alkaloid ellipticine are of great interest because in vitro and in vivo studies revealed their good cytotoxic properties. In order to obtain some biologically active analogs of these compounds, we developed a synthesis based on the photocyclization of tertiary $N$-substituted enaminones derived from 1,3-cyclohexandione and 3 or 6 -aminoquinoline. The angular cyclized compounds thus obtained were tested in vitro on K 562 cells and A 2780 doxorubicin sensitive and resistant cells. All compounds were less effective than doxorubicin in sensitive cells but their activity wasn't decreased by MDR resistance.
\end{abstract}

Key words indoloquinoline; pyridocarbazole; photochemistry; cytotoxicity

Interest in the chemistry of pyridocarbazoles and indoloquinolines has increased this last decade since these skeletons are present in a large number of alkaloids of biological interest. For example, the indoloquinoline type alkaloid cryptolepine 1 (Fig. 1) extracted from the roots of Cryptolepis sanguinolenta ${ }^{1)}$ has been shown to exhibit antiplasmodial, ${ }^{2)}$ antibacterial ${ }^{3)}$ and cytotoxic properties. ${ }^{4,5)}$ This last activity is due to cryptolepine intercalation into DNA and subsequent inhibition of DNA religation by topoisomerase II. ${ }^{5}$ Another example concerns the pyridocarbazole type alkaloid ellipticine 2 (Fig. 1) extracted from the leaves of Ochrosia ellip$t_{\left.i c a^{6}\right)}$ which has exhibited cytotoxic properties by different mechanisms : intercalation into DNA ${ }^{7}{ }^{7}$ inhibition of topoisomerase $\mathrm{II},{ }^{8)}$ formation of covalent adducts with DNA after bioactivation, ${ }^{9)}$ stimulation of apoptosis. ${ }^{10)}$ Different linear and angular analogs of these compounds have already been synthetized by several groups ${ }^{11-17)}$ but the series of indolo[2,3-c]quinoline and pyrido[2,3-c]carbazole haven't been studied yet.

Therefore, as a part of our program concerning the elaboration of analogs of natural products, we are interested in the chemistry as well as in the biological activities of these angular heterocycles. ${ }^{18,19)}$ Our methodology resides in the photocyclization of enaminones derived from 3 or 6-aminoquinoline (Fig. 1). Enaminones represent convenient tools in hete-

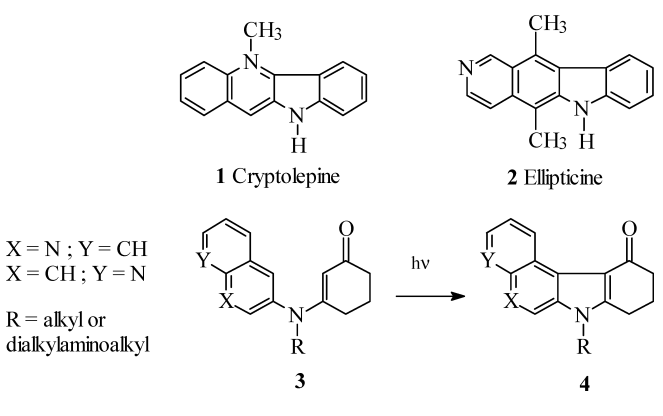

Fig. 1 rocyclic chemistry since they can be implicated in the elaboration of carbazoles, ${ }^{20)} \alpha$-carbolines, ${ }^{21)} \beta$-carbolines and $\delta$ carbolines. ${ }^{22,23)}$ The photocyclization can occur through an electrocyclization for tertiary enaminones or through a radical process for halogenated enaminones. ${ }^{24)}$ Furthermore, in our recent works, we obtained $N$-benzylpyridocarbazoles and indoloquinolines from tertiary $N$-benzylenaminones ${ }^{25}$ and non $N$-substituted compounds from secondary iodinated enaminones. ${ }^{26)}$ In the present work, we investigate the reactivity of tertiary enaminones carrying an alkyl or a dialkylaminoalkyl side chain 3 and report the results of in vitro cytotoxicity studies of the obtained cyclized compounds 4 .

\section{Chemistry}

Firtsly, the reactivity of tertiary enaminones derived from 3 -aminoquinoline was studied. According to previously described procedures, ${ }^{22,23,25,26)}$ the secondary enaminone 7 is obtained by condensation of 3-aminoquinoline 5 and 1,3-cyclohexandione $\mathbf{6}$ in toluene with catalytic amounts of $p$-toluenesulfonic acid. Then, a methyl or a diethylaminoethyl side chain was introduced on the enaminone nitrogen by treating secondary enaminone 7 by sodium hydride, and then by methyl iodide or by the hydrochloride salt of diethylaminoethylchloride to give $\mathbf{8}$ and 9 . The dimethylaminopropyl side chain couldn't be introduced following this protocole. However, the tertiary enaminone $\mathbf{1 0}$ was obtained by treating compound 7 with the hydrochloride salt of dimethylaminopropylchloride in presence of sodium hydride in dimethylformamide (DMF) ${ }^{27)}$ (Fig. 2).

The methyl substituent was chosen because structureactivity relationships studies realized on ellipticine and cryptolepine linear or angular analogs show the contribution of the $N$-methyl function to the cytotoxicity and a frequent loss of activity with bigger alkyl chains. ${ }^{11,28,29)}$ Dialkylaminoalkyl chains were chosen because they're often described as cytotoxicity enhancers, probably through a stabilisation of the drug-DNA interaction. ${ }^{30,31)}$ 
Irradiation of enaminones $\mathbf{8 , 9 , 1 0}$ to give respectively $\mathbf{1 1}$, 12, 13, were performed using a Pyrex well apparatus and a medium pressure mercury UV lamp $(150 \mathrm{~W})$ under a set of conditions (Fig. 3, Table 1).

These photocyclizations were regioselective on the C-4 position of the quinolinic nucleus since only angular compounds were obtained. Structure of 11, 12, 13 was easily determined by ${ }^{1} \mathrm{H}-\mathrm{NMR}$, and by comparison with our previous results. ${ }^{25,26)}$ More precisely the ${ }^{1} \mathrm{H}-\mathrm{NMR}$ spectrum of 11, 12, 13 showed characteristic signals of $\mathrm{H}-1$ shifted downfield due to the proximity of the carbonyl group and appeared as double doublets ( $\delta 9.68$ for $\mathbf{1 1}, \delta 9.81$ for $\mathbf{1 2}, \delta 9.74$ for 13 ). The $N$-substituents don't change the regioselectivity previously observed with $N$-benzylated enaminones ${ }^{25}$ ) and with secondary iodinated enaminones. ${ }^{26)}$ Yields of photocyclization were close to those previously obtained: Compound $\mathbf{1 1}$ was obtained with the best yield $(80 \%)$ with methanol as solvent, while the substituted indoloquinolines $\mathbf{1 2}$ and $\mathbf{1 3}$ were obtained respectively with a $60 \%$ and a $35 \%$ yield (other conditions led to massive decomposition of the enaminone and poor yields of cyclized compounds). Compounds 11, 12 and

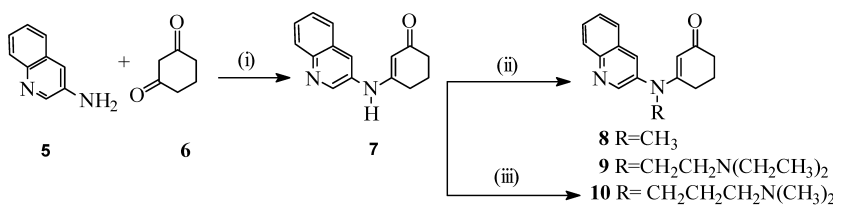

reagents and conditions:

(i) toluene, pTSA, reflux

(ii) $\mathrm{NaH}$, toluene, $\mathrm{RX}\left(\mathrm{CH}_{3} \mathrm{I}\right.$ for $8, \mathrm{ClCH}_{2} \mathrm{CH}_{2} \mathrm{~N}\left(\mathrm{CH}_{2} \mathrm{CH}_{3}\right)_{2} \cdot \mathrm{HCl}$ for 10

(iii) $\mathrm{NaH}, \mathrm{DMF}, \mathrm{Cl}\left(\mathrm{CH}_{2}\right)_{3} \mathrm{~N}\left(\mathrm{CH}_{3}\right)_{2} \cdot \mathrm{HCl}$

Fig. 2

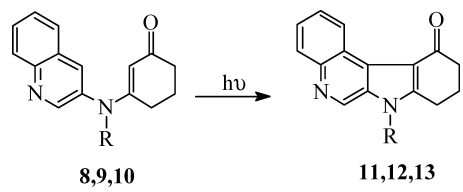

Fig. 3

Table 1. Irradiation of Tertiary Enaminones 8, 9, 19

\begin{tabular}{crlr}
\hline \hline Entry & \multicolumn{1}{c}{ Substrate } & \multicolumn{1}{c}{ Conditions } & $\begin{array}{c}\text { Yield (\%) } \\
\text { of compd. }\end{array}$ \\
\hline 1 & $\mathbf{8 ~ R}=\mathrm{CH}_{3}$ & Pyrex, methanol, 4h & $\mathbf{1 1}(80)$ \\
2 & $\mathbf{8 ~ R}=\mathrm{CH}_{3}$ & Pyrex, toluene, 4h & $\mathbf{1 1}(55)$ \\
3 & $\mathbf{8 ~ R}=\mathrm{CH}_{3}$ & Pyrex, methanol/toluene $50 / 50,4 \mathrm{~h}$ & $\mathbf{1 1}(70)$ \\
4 & $\mathbf{9 ~ R}=\left(\mathrm{CH}_{2}\right)_{2} \mathrm{~N}(\mathrm{Et})_{2}$ & Pyrex, methanol, 4h & $\mathbf{1 2}(60)$ \\
5 & $\mathbf{1 0 ~ R}=\left(\mathrm{CH}_{2}\right)_{3} \mathrm{~N}(\mathrm{Me})_{2}$ & Pyrex, methanol, 4h & $\mathbf{1 3}(35)$ \\
\hline
\end{tabular}

13 were retained for biological studies.

Then, so as to study the influence of the position of the quinolinic nitrogen on the reactivity of such enaminones, the secondary enaminone 15 was prepared by condensation of 6-aminoquinoline $\mathbf{1 4}$ and 1,3-cyclohexandione $\mathbf{6}$ in toluene with $p$-toluenesulfonic acid. Then, tertiary enaminones $\mathbf{1 6}$, 17 and 18 were obtained by treatment of 15 with sodium hydride in toluene and then, by methyl iodide, ethyl iodide or diethylaminoethyl hydrochloride. Tertiary enaminone 19 was also obtained by treatment of $\mathbf{1 5}$ with dimethylaminopropylchloride hydrochloride in DMF in presence of sodium hydride (Fig. 4). The $N$-ethyl derivative 17 was prepared because the first biological results showed a better activity of the 6-aminoquinoline derivatives, so we wanted to test other alkyl side chains, with the hope of increasing cytotoxicity.

Then, these four tertiary enaminones were subjected to irradiation in a pyrex reactor under different conditions (Fig. 5, Table 2).

The results of these irradiations were quite surprising, since we obtained a mixture of the expected 8,9,10,11tetrahydropyridocarbazoles $\mathbf{2 4}, \mathbf{2 5}, \mathbf{2 6}$, and $\mathbf{2 7}$ and of 5,6,8,9,10,11-hexahydropyridocarbazoles 20, 21, 22 and 23. In all cases, only angular compounds, identified easily thanks to the chemical shift of proton $\mathrm{H}-1$, were obtained, confirming the perfect regioselectivity of this photocyclization. The global yields of photocyclization were smaller than those obtained with 3-aminoquinoline derivatives and confirm the lower reactivity of 6-aminoquinoline derivatives, previously described. ${ }^{25,26)}$ As the influence of solvent is a well-known phenomenon in photochemistry, it was hypothetised that irradiation in another solvent such as toluene could modify the

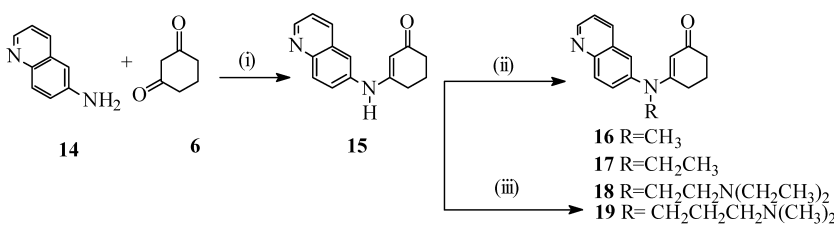

reagents and conditions:

(iv) toluene, pTSA, reflux

(v) $\mathrm{NaH}$, toluene, $\mathrm{RX}\left(\mathrm{CH}_{3} \mathrm{I}\right.$ for $16, \mathrm{C}_{2} \mathrm{H}_{5} \mathrm{I}$ for $17, \mathrm{ClCH}_{2} \mathrm{CH}_{2} \mathrm{~N}\left(\mathrm{CH}_{2} \mathrm{CH}_{3}\right)_{2} \cdot \mathrm{HCl}$ for 18 (vi) $\mathrm{NaH}, \mathrm{DMF}, \mathrm{Cl}\left(\mathrm{CH}_{2}\right)_{3} \mathrm{~N}\left(\mathrm{CH}_{3}\right)_{2} \cdot \mathrm{HCl}$

Fig. 4

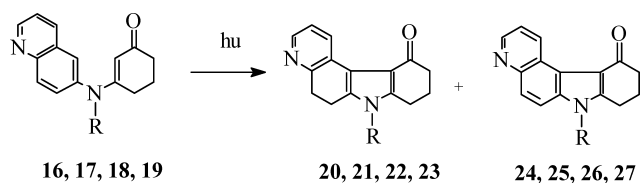

Fig. 5

Table 2. Irradiation of Tertiary Enaminones 16, 17, 18, 19

\begin{tabular}{|c|c|c|c|c|}
\hline Entry & Substrate & Conditions & Yield $(\%)$ of compd. & Global yield (\%) \\
\hline 1 & $16 \mathrm{R}=\mathrm{CH}_{3}$ & Pyrex, methanol, $4 \mathrm{~h}$ & $\mathbf{2 0}(56)$ and $\mathbf{2 4}(44)$ & 40 \\
\hline 2 & $17 \mathrm{R}=\mathrm{CH}_{2} \mathrm{CH}_{3}$ & Pyrex, methanol, $4 \mathrm{~h}$ & $21(85)$ and $25(15)$ & 50 \\
\hline 3 & $18 \mathrm{R}=\left(\mathrm{CH}_{2}\right)_{2} \mathrm{~N}(\mathrm{Et})_{2}$ & Pyrex, methanol, $4 \mathrm{~h}$ & $22(95)$ and $26(5)$ & 40 \\
\hline 4 & $19 \mathrm{R}=\left(\mathrm{CH}_{2}\right)_{3} \mathrm{~N}(\mathrm{Et})_{2}$ & Pyrex, methanol, $4 \mathrm{~h}$ & $\mathbf{2 3}(80)$ and $27(20)$ & 40 \\
\hline 5 & $16 \mathrm{R}=\mathrm{CH}_{3}$ & Pyrex, toluene, $4 \mathrm{~h}$ & $\mathbf{2 0}(40)$ and $24(60)$ & 50 \\
\hline 6 & $17 \mathrm{R}=\mathrm{CH}_{2} \mathrm{CH}_{3}$ & Pyrex, toluene, $4 \mathrm{~h}$ & 21 (5) and 25 (95) & 40 \\
\hline 7 & $18 \mathrm{R}=\left(\mathrm{CH}_{2}\right)_{2} \mathrm{~N}(\mathrm{Et})_{2}$ & Pyrex, toluene, $4 \mathrm{~h}$ & $22(10)$ and $26(90)$ & 25 \\
\hline 8 & $19 \mathrm{R}=\left(\mathrm{CH}_{2}\right)_{3} \mathrm{~N}(\mathrm{Et})_{2}$ & Pyrex, toluene, $4 \mathrm{~h}$ & $23(25)$ and $27(75)$ & 60 \\
\hline
\end{tabular}




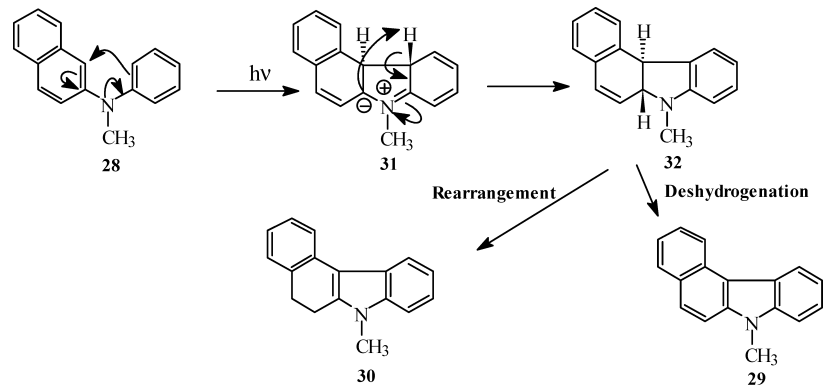

Fig. 6

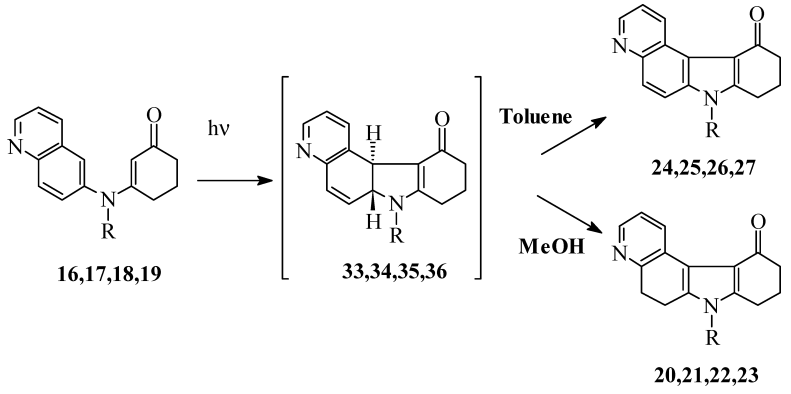

Fig. 7 ratio hexahydro/terahydro compound. So, compounds $\mathbf{1 6}, \mathbf{1 7}$, 18 and 19 were irradiated in a pyrex reactor in toluene for $4 \mathrm{~h}$. The ratios reduced/non reduced compound were reversed and non-reduced compounds were largely predominant, except in the case of the $N$-methyl derivative, whose photocyclization seemed to be poorly influenced by the solvent of irradiation.

This C5-C6 bond reduction had already been established when photocyclization of secondary iodinated enaminone derived from 6-aminoquinoline was conducted in a pyrex reactor using acetonitrile with $4 \mathrm{ml}$ of triethylamine as solvent. ${ }^{26}$ ) Only the hexahydro compound was obtained. Furthermore, this reduction could be understood as the result of a photoinduced electron transfer from triethylamine to the aromatic system, followed by abstraction of a proton and an hydrogen radical from the solvent, as described by Yang et al. ${ }^{32)}$ But, in the present case, the reaction mixture didn't contain any triethylamine, so this phenomenon can't explain the photoreduction. $6 \pi$ electron mechanism is implicated in the photocyclization of such tertiary enaminones. According to this mechanism, described by Grellman et al. ${ }^{33)}$ and Chapman et $a l .,{ }^{34)}$ a zwitterionic species is initially formed, which gives a hexahydro compound, which can eventually undergo a dehydrogenation process to give a tetrahydro compound. Furthermore, Grellman et al. ${ }^{35)}$ have irradiated the $N$-methyl-2-anilinonaphtalene $\mathbf{2 8}$ in different solvents and have obtained a mixture of 5-methylbenzo[c]carbazole 29 and 5-methyl-6,7dihydrobenzo[c]carbazole 30 (2:1 ratio). A hypothesis was proposed by the authors to explain the formation of those two compounds: after the electrocyclisation, the zwitterionic intermediate 31 undergoes a suprafacial 1,4 hydrogen shift. The resulting compound $\mathbf{3 2}$ can either undergo an internal rearrangement to give $\mathbf{3 0}$ or undergo dehydrogenation to give 29 (Fig. 6).

This hypothesis can be applied to our compounds and therefore may explain the results presented above: irradiation of tertiary enaminones $16,17,18,19$ should give the intermediary hexahydro derivatives $33,34,35,36$. Toluene induces dehydrogenation to give $\mathbf{2 4}, \mathbf{2 5}, \mathbf{2 6}, 27$ whereas methanol induces rearrangement to give $\mathbf{2 0}, \mathbf{2 1}, \mathbf{2 2}, \mathbf{2 3}$, as shown in Fig. 7.

A second phenomenon which happens after cyclization and dehydrogenation might explain $\mathrm{C}_{5}-\mathrm{C}_{6}$ bond reduction. Some authors ${ }^{36-38)}$ described the reduction of one bond of aromatic compounds when they underwent irradiation in proton donnors solvents, particularly aliphatic alcohols. Methanol could contribute to the reduction via this pathway. However, this phenomenon doesn't explain the formation of

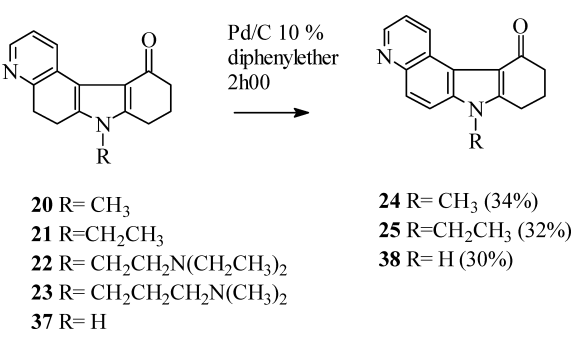

Fig. 8

reduced compounds when the $N$-substituted derivatives were irradiated in toluene alone. Yet we can reasonably suppose that solvent influence on the rearrangement or the dehydrogenation is the most important phenomenon and that photoreduction of tetrahydro cyclized compound by methanol may contribute to the formation of reduced compounds.

Finally, we investigated the strategy which consist in treating reduced compounds by $\mathrm{Pd} / \mathrm{C} 10 \%$ in diphenylether. ${ }^{39)}$ This reaction was successful in the case of the non- $N$-substituted pyridocarbazole $\mathbf{3 7}^{26}$ which gave the compound $\mathbf{3 8}^{26}$ ) with a $30 \%$ yield. $N$-Methyl and $N$-ethyl compounds 24 and 25 were obtained from 20 and 21 with a 30\% yield. But, unfortunately, compounds $\mathbf{2 2}$ and $\mathbf{2 3}$ underwent massive degradation (Fig. 8).

\section{Biological Results}

In continuation of our previous works ${ }^{40,41)}$ concerning the antiproliferative activity of tetracyclic nitrogenous heterocycles, and more precisely, their activity against MDR + cancer cells lines, the cytotoxicity of the compounds 11, 12, 13, 24, 25, 26, 37, 38 and 39, as the non $N$-substituted indoloquinoline previously prepared ${ }^{26}$ was evaluated by a cell growth inhibition assay against two human cell lines: K 562 (leukemia), and A 2780 (ovarian cancer) doxorubicin-sensitive and resistant (MDR + ) and was compared to the cytotoxicity of doxorubicin. The resistant subline A 2780 R was established by the continuous exposure of cells to gradually increasing concentrations of doxorubicin. The resistant subline K $562 \mathrm{R}$ wasn't tested because of the poor activity of our products against $\mathrm{K} 562 \mathrm{~S}$ cells. $\mathrm{IC}_{50}$ (concentration inhibiting $50 \%$ of the cell proliferation) expressed in $\mathrm{mol} / \mathrm{l}$ and resistance factor $\left(\mathrm{IC}_{50}\right.$ on $\mathrm{A} 2780$ resistant cells/ $\mathrm{IC}_{50}$ on $\mathrm{A} 2780$ sensitive cells) of each compound are recapitulated in Table 3.

All the compounds are 10 to 1000 fold less effective than doxorubicin in all sensitive cells whereas compounds 11, 24 and $\mathbf{2 6}$ are as active as doxorubicin on A 2780 resistant cells 
Table 3. $\mathrm{IC}_{50}$ and Resistance Factor of Tested Compounds and Doxorubicin

\begin{tabular}{ccccc}
\hline \hline Compds. & $\begin{array}{c}\text { K 562 cells } \\
(\mathrm{mol} / \mathrm{l})\end{array}$ & $\begin{array}{c}\text { A } 2780 \text { sensitive cells } \\
(\mathrm{mol} / \mathrm{l})\end{array}$ & $\begin{array}{c}\text { A } 2780 \text { resistant cells } \\
(\mathrm{mol} / \mathrm{l})\end{array}$ \\
\hline $\mathbf{1 1}$ & $4.6 \times 10^{-5} \pm 2.8 \times 10^{-6}$ & $8.0 \times 10^{-6} \pm 6.3 \times 10^{-6}$ & $8.3 \times 10^{-6} \pm 4.0 \times 10^{-7}$ \\
$\mathbf{1 2}$ & $2.1 \times 10^{-5} \pm 1.0 \times 10^{-6}$ & $4.0 \times 10^{-5} \pm 2.6 \times 10^{-5}$ & $9.0 \times 10^{-5} \pm 2.8 \times 10^{-6}$ & 1 \\
$\mathbf{1 3}$ & $1.5 \times 10^{-5} \pm 1.0 \times 10^{-6}$ & $3.8 \times 10^{-5} \pm 3.2 \times 10^{-6}$ & $9.5 \times 10^{-5} \pm 1.1 \times 10^{-6}$ & 2.3 \\
$\mathbf{2 4}$ & $3.3 \times 10^{-5} \pm 2.0 \times 10^{-6}$ & $2.0 \times 10^{-6} \pm 1.0 \times 10^{-6}$ & $5.8 \times 10^{-6} \pm 2.4 \times 10^{-6}$ & 2.5 \\
$\mathbf{2 5}$ & $7.8 \times 10^{-6} \pm 1.8 \times 10^{-6}$ & $1.4 \times 10^{-5} \pm 5.9 \times 10^{-6}$ & $1.7 \times 10^{-5} \pm 1.0 \times 10^{-5}$ & 1.2 \\
$\mathbf{2 6}$ & $2.5 \times 10^{-5} \pm 3.0 \times 10^{-6}$ & $2.8 \times 10^{-6} \pm 1.7 \times 10^{-6}$ & $2.8 \times 10^{-6} \pm 1.8 \times 10^{-7}$ & 1 \\
$\mathbf{3 7}$ & $8.8 \times 10^{-5} \pm 1.3 \times 10^{-5}$ & $2.2 \times 10^{-5} \pm 1.1 \times 10^{-5}$ & $2.8 \times 10^{-5} \pm 2.0 \times 10^{-5}$ & 1.3 \\
$\mathbf{3 8}$ & $2.3 \times 10^{-5} \pm 1.2 \times 10^{-6}$ & $1.4 \times 10^{-5} \pm 7.8 \times 10^{-5}$ & $2.5 \times 10^{-5} \pm 4.6 \times 10^{-6}$ & 1.8 \\
$\mathbf{3 9}$ & $9.3 \times 10^{-5} \pm 2.6 \times 10^{-5}$ & $3.3 \times 10^{-5} \pm 4.2 \times 10^{-5}$ & $4.2 \times 10^{-5} \pm 5.5 \times 10^{-6}$ & 1.3 \\
Dox $^{b)}$ & $1.6 \times 10^{-7} \pm 3.3 \times 10^{-8}$ & $2.4 \times 10^{-8} \pm 4.0 \times 10^{-9}$ & $2.9 \times 10^{-6} \pm 4.9 \times 10^{-7}$ & 121
\end{tabular}

a) resistance factor, $b$ ) dox $=$ doxorubicin.

with $\mathrm{IC}_{50}$ varying between 2.8 and $8.3 \times 10^{-6} \mathrm{~mol} / 1$. The other compounds are only 10 fold less active than doxorubicin on A $2780 \mathrm{R}$ cells. The resistance factor of all those compounds varies between 1 and 2.9 (doxorubicin: 121), which indicates that these compounds, as most synthetic compounds, are not concerned by the multidrug resistance phenomenon.

Comparison of $\mathrm{IC}_{50}$ values of the hexahydro compound 37 and the tetrahydro compound $\mathbf{3 8}$ shows this reduction doesn't seem to influence the biological activity, in spite of the twisted structure of the reduced compound. Whatever the $N$ substituent is, $\mathrm{IC}_{50}$ of 3-aminoquinoline derivatives are, in most cases, equal or higher than $\mathrm{IC}_{50}$ of 6 -aminoquinoline derivatives, proving that 6-aminoquinoline series gives more active compounds. About the influence of the $N$-substituent, it appears that the $N$-methyl compound $\mathbf{1 1}$ is the most active of the 3-aminoquinoline derivatives and that $N$-methyl and $N$ diethylaminoethyl compounds $\mathbf{2 4}$ and $\mathbf{2 6}$ are the most active of the 6-aminoquinoline derivatives, thus proving the role of the $N$-methyl group in the cytotoxic activity and the role of dialkylaminoalkyl side chains in cytotoxicity enhancement.

Compounds 11, 24 and 26, the most active ones, are good candidates for further in vivo studies.

\section{Conclusion}

In this paper, we have reported the synthesis of $N$-substituted tetracyclic nitrogen heterocycles: indoloquinolines and pyridocarbazoles. The photochemical key step which provides cyclized compounds from $N$-alkyl or $N$-dialkylaminoalkyl enaminones occures with a total regioselectivity, since only angular compounds are obtained. An unexpected photoreduction phenomenon occured during irradiation and was shown to be greatly influenced by the solvent. The first in vitro studies reveal that the main interest of these compounds resides in their activity toward resistant cells. Further studies on the pharmacomodulation of such compounds are now in progress and should lead to an interesting class of new potential anticancer agents with no multidrug resistance phenomena.

\section{Experimental}

${ }^{1} \mathrm{H}$ - and ${ }^{13} \mathrm{C}$-NMR spectra were recorded on a Brüker AC 100 or EM 400 WB. Chemical shift data are reported in ppm downfield $\delta$ from TMS. Coupling constants $J$ are given in Hz. s, d, dd, t, q, and m mean respectively singlet, doublet, double doublet, triplet, quadruplet and multiplet. Melting points were determined on a Büchi capillary melting point apparatus and are not corrected. Elemental analysis was performed by Microanalytical center, ENSCM, Montpellier.

Irradiations were conducted in a pyrex well apparatus using a medium pressure mercury UV lamp (Heraeus TQ 150). Total volume of solvent(s) was about $350-400 \mathrm{ml}$. In order to remove oxygen, the reaction mixture was submitted to ultrasound waves for $10 \mathrm{~min}$ before irradiation. Besides, during the irradiation, the reaction mixture was flushed with a stream of nitrogen.

3-[(3'-Quinolinyl)methylamino|cyclohex-2-en-1-one 8 Compound 7 $(1 \mathrm{~g}, 4.2 \mathrm{mmol})$ was added to a suspension of sodium hydride $(1 \mathrm{~g}, 25 \mathrm{mmol}$, $60 \%$ in mineral oil) in anhydrous toluene $(50 \mathrm{ml})$. The mixture was refluxed under nitrogen for $2 \mathrm{~h}$ and cooled to room temperature. Methyl iodide $(5 \mathrm{ml}$, $80 \mathrm{mmol}$ ) was then added and the mixture was refluxed for $3 \mathrm{~h}$. After cooling, toluene was washed with water and the insoluble residue was dissolved in dichloromethane and washed with water. The organic layers were dried over sodium sulfate and evaporated in vacuo. The crude product was chromatographed on silica gel with dichloromethane and a gradient of methanol as eluent to give 8 as a white powder: $45 \%, \mathrm{mp} 128-130^{\circ} \mathrm{C} .{ }^{1} \mathrm{H}-\mathrm{NMR}$ $\left(\mathrm{CDCl}_{3}\right) \delta: 1.91(2 \mathrm{H}, \mathrm{m}), 2.28(4 \mathrm{H}, \mathrm{m}), 3.32(3 \mathrm{H}, \mathrm{s}), 5.37(1 \mathrm{H}, \mathrm{s}), 7.58(1 \mathrm{H}$, m), $7.76(2 \mathrm{H}, \mathrm{m}), 7.90(1 \mathrm{H}, \mathrm{d}, J=2.2 \mathrm{~Hz}), 8.11(1 \mathrm{H}, \mathrm{d}, J=8.1 \mathrm{~Hz}), 8.71(1 \mathrm{H}$ d, $J=2.3 \mathrm{~Hz}) ;{ }^{13} \mathrm{C}-\mathrm{NMR}\left(\mathrm{CDCl}_{3}\right) \delta: 22.2,29.3,35.8,40.7,101.7,127.4$ (3C), 129.0, 129.7, 132.5, 138.4, 146.3, 149.4, 164.2, 197.3; Anal. Calcd for $\mathrm{C}_{16} \mathrm{H}_{16} \mathrm{~N}_{2} \mathrm{O}$ : C, 76.19; H, 6.35; N, 11.11. Found: C, 76.30; H, 6.35; N, 11.08 .

3-[(3'-Quinolinyl)diethylaminoethylamino]cyclohex-2-en-1-one 9 Compound $7(0.5 \mathrm{~g}, 2.1 \mathrm{mmol})$ was added to a suspension of sodium hydride $(1 \mathrm{~g}, 25 \mathrm{mmol}, 60 \%$ in mineral oil) in anhydrous toluene $(50 \mathrm{ml})$. The $\mathrm{mix}-$ ture was refluxed under nitrogen for $2 \mathrm{~h}$ and cooled to room temperature. Diethylaminoethylchloride hydrochloride $(0.4 \mathrm{~g}, 2.3 \mathrm{mmol})$ was then added and the mixture was refluxed for $2 \mathrm{~h}$. After cooling, toluene was washed with water and the insoluble residue was dissolved in dichloromethane and washed with water. The organic layers were dried over sodium sulfate and evaporated in vacuo. The crude product was chromatographed on alumina gel with ether and a gradient of methanol as eluent to give $\mathbf{9}$ as a yellow oil: $35 \%$. ${ }^{1} \mathrm{H}-\mathrm{NMR}\left(\mathrm{CDCl}_{3}\right) \delta: 0.88(6 \mathrm{H}, \mathrm{t}, J=7.0 \mathrm{~Hz}), 1.89(2 \mathrm{H}, \mathrm{m}), 2.26(4 \mathrm{H}$, $\mathrm{m}), 2.42(\mathrm{q}, 4 \mathrm{H}, J=7.0 \mathrm{~Hz}), 2.67(2 \mathrm{H}, \mathrm{t}, J=6.9 \mathrm{~Hz}), 3.73(2 \mathrm{H}, \mathrm{t}, J=6.9 \mathrm{~Hz})$, $5.35(1 \mathrm{H}, \mathrm{s}), 7.69(3 \mathrm{H}, \mathrm{m}), 8.1(2 \mathrm{H}, \mathrm{m}), 8.75(1 \mathrm{H}, \mathrm{d}, J=2.3 \mathrm{~Hz}) ;{ }^{13} \mathrm{C}-\mathrm{NMR}$ $\left(\mathrm{CDCl}_{3}\right) \delta: 11.3(2 \mathrm{C}), 22.0,29.1,35.6,46.7$ (2C), 49.6, 51.3, 101.1, 127.0, 127.2, 128.8, 129.4, 133.3, 137.5, 146.1, 150.2, 163.5, 196.8. Anal. Calcd for $\mathrm{C}_{21} \mathrm{H}_{27} \mathrm{~N}_{3} \mathrm{O}$ : C, 74.78; H, 8.01; N, 12.46. Found: C, 74.61; H, 8.02; N, 12.37 .

3-[(3'-Quinolinyl)dimethylaminopropylamino]cyclohex-2-en-1-one 10 Compound $7(0.5 \mathrm{~g}, 2.1 \mathrm{mmol})$ and dimethylaminopropylchloride hydrochloride $(0.4 \mathrm{~g}, 2.53 \mathrm{mmol})$ were added to a suspension of sodium hydride $(1 \mathrm{~g}$, $25 \mathrm{mmol}, 60 \%$ in mineral oil) in dimethylformamide $(10 \mathrm{ml})$. The mixture was refluxed under nitrogen for $3 \mathrm{~h}$ and cooled to room temperature. Then, methanol was added to neutralize sodium hydride excess, followed by water $(30 \mathrm{ml})$. After extraction with dichloromethane $(3 \times 50 \mathrm{ml})$, the organic layers were dried over sodium sulfate and evaporated in vacuo. The crude product was chromatographed on silica gel with ether and a gradient of methanol as eluent to give $\mathbf{1 0}$ as a yellow oil: $34 \% .{ }^{1} \mathrm{H}-\mathrm{NMR}\left(\mathrm{CDCl}_{3}\right) \delta: 1.87(4 \mathrm{H}, \mathrm{m})$, $2.11(6 \mathrm{H}, \mathrm{s}), 2.26(6 \mathrm{H}, \mathrm{m}), 3.70(2 \mathrm{H}, \mathrm{t}, J=7.3 \mathrm{~Hz}), 5.35(1 \mathrm{H}, \mathrm{s}), 7.71(4 \mathrm{H}$, $\mathrm{m}), 8.11(1 \mathrm{H}, \mathrm{d}, J=8.3 \mathrm{~Hz}), 8.67(1 \mathrm{H}, \mathrm{d}, J=2.2 \mathrm{~Hz}) ;{ }^{13} \mathrm{C}-\mathrm{NMR}\left(\mathrm{CDCl}_{3}\right) \delta$ : $22.7,25.4,29.0,36.4,45.6,51.6,56.7,101.9,128.0,128.0,128.2(3 \mathrm{C})$, 129.6, 130.4, 134.2, 137.6, 147.0, 150.6, 164.5, 197.8. Anal. Calcd for $\mathrm{C}_{20} \mathrm{H}_{25} \mathrm{~N}_{3} \mathrm{O}: \mathrm{C}, 74.30 ; \mathrm{H}, 7.74 ; \mathrm{N}, 13.0$. Found: C, 74.50; H, 7.76; N, 12.89 .

7-Methyl-8,9,10,11-tetrahydroindolo[2,3-c]quinolin-11-one 11 Compound $8(0.4 \mathrm{~g}, 1.6 \mathrm{mmol})$ underwent irradiation under different conditions (see Table 1). Then, the solvents were evaporated under reduced pressure. The crude product was chromatographed on silica gel using dichloromethane and 
a gradient of methanol as eluent to give $\mathbf{1 1}$ as a white powder: $80 \%$ (best yield), mp $238-240{ }^{\circ} \mathrm{C} .{ }^{1} \mathrm{H}-\mathrm{NMR}\left(\mathrm{CDCl}_{3}\right) \delta: 2.08(2 \mathrm{H}, \mathrm{m}), 2.35(2 \mathrm{H}, \mathrm{t}$, $J=6.2 \mathrm{~Hz}), 2.54(2 \mathrm{H}, \mathrm{t}, J=6.3 \mathrm{~Hz}), 3.16(3 \mathrm{H}, \mathrm{s}), 7.63(2 \mathrm{H}, \mathrm{m}), 8.12(1 \mathrm{H}, \mathrm{dd}$, $J=6.7,1.5 \mathrm{~Hz}), 8.52(1 \mathrm{H}, \mathrm{s}), 9.68(1 \mathrm{H}, \mathrm{dd}, J=6.6,1.5 \mathrm{~Hz}) ;{ }^{13} \mathrm{C}-\mathrm{NMR}$ $\left(\mathrm{CDCl}_{3}\right) \delta: 22.2,22.5,29.9,39.0,114.7,123.3,125.9,126.2,127.4,128.6$, $129.5,129.9,135.3,144.3,152.7,193.4$. Anal. Calcd for $\mathrm{C}_{16} \mathrm{H}_{14} \mathrm{~N}_{2} \mathrm{O}$ : C, $76.80 ; \mathrm{H}, 5.60 ; \mathrm{N}, 11.20$. Found: $\mathrm{C}, 76.75 ; \mathrm{H}, 5.62 ; \mathrm{N}, 11.17$

7-(N,N-Diethylaminoethyl)-8,9,10,11-tetrahydroindolo[2,3-c]quinolin11-one 12 Compound $9(0.3 \mathrm{~g}, 0.9 \mathrm{mmol})$ underwent irradiation for $2 \mathrm{~h}$ in a pyrex reactor using methanol as solvent. Then, the solvents were evaporated under reduced pressure. The crude product was chromatographed on silica gel using dichloromethane and a gradient of methanol as eluent to give 12 as a yellow oil: $60 \%$ (best yield). ${ }^{1} \mathrm{H}-\mathrm{NMR}\left(\mathrm{CDCl}_{3}\right) \delta: 0.86(6 \mathrm{H}, \mathrm{t}$ $J=6.7 \mathrm{~Hz}), 2.24(2 \mathrm{H}, \mathrm{m}), 2.47(4 \mathrm{H}, \mathrm{q}, J=6.7 \mathrm{~Hz}), 2.74(4 \mathrm{H}, \mathrm{m}), 2.99(2 \mathrm{H}, \mathrm{t}$, $J=6.1 \mathrm{~Hz}), 4.19(2 \mathrm{H}, \mathrm{t}, J=6.8 \mathrm{~Hz}), 7.64(2 \mathrm{H}, \mathrm{m}), 8.15(1 \mathrm{H}, \mathrm{m}), 8.95(1 \mathrm{H}, \mathrm{s})$ $9.81(1 \mathrm{H}, \mathrm{m}) ;{ }^{13} \mathrm{C}-\mathrm{NMR}\left(\mathrm{CDCl}_{3}\right) \delta: 11.60\left(2 \mathrm{C}, \mathrm{CH}_{3} 4^{\prime}\right), 22.39(2 \mathrm{C}, \mathrm{C} 8, \mathrm{C} 9)$, 38.80 (C10), $43.09\left(\mathrm{CH}_{2} 1^{\prime}\right), 47.55\left(2 \mathrm{C}, \mathrm{CH}_{2} 3^{\prime}\right), 52.55\left(\mathrm{CH}_{2} 2^{\prime}\right), 114.49$ (C11a), 123.19 (C11b), $125.71(\mathrm{C} 3), 125.95$ (C11c), 126.63 (C2), 128.22 (C1), 129.00 (C4), 129.27 (C6a), 135.38 (C6), 144.09 (C4a), 152.58 (C7a), 193.00 (C11). Anal. Calcd for $\mathrm{C}_{21} \mathrm{H}_{25} \mathrm{~N}_{3} \mathrm{O}$ : C, 75.22; H, 7.46; N, 12.54 Found: C, 75.34; H, 7.45; N, 12.48

7-(N,N-Dimethylaminopropyl)-8,9,10,11-tetrahydroindolo $[2,3-$ clquinolin-11-one 13 Compound $10(0.23 \mathrm{~g}, 0.7 \mathrm{mmol})$ underwent irradiation for $2 \mathrm{~h}$ in a pyrex reactor using methanol as solvent. Then, the solvents were evaporated under reduced pressure. The crude product was chromatographed on alumina gel using dichloromethane and a gradient of methanol as eluent to give $\mathbf{1 3}$ as an orange oil: $35 \%$ (best yield). ${ }^{1} \mathrm{H}-\mathrm{NMR}$ $\left(\mathrm{CDCl}_{3}\right) \delta: 1.81(2 \mathrm{H}, \mathrm{m}), 2.06(2 \mathrm{H}, \mathrm{m}), 2.09(6 \mathrm{H}, \mathrm{s}), 2.15(2 \mathrm{H}, \mathrm{t}, J=6.4 \mathrm{~Hz})$, $2.57(2 \mathrm{H}, \mathrm{t}, J=6.1 \mathrm{~Hz}), 2.76(2 \mathrm{H}, \mathrm{t}, J=6.2 \mathrm{~Hz}), 4.02(2 \mathrm{H}, \mathrm{t}, J=7 \mathrm{~Hz}), 7.58$ $(2 \mathrm{H}, \mathrm{m}), 8.08(1 \mathrm{H}, \mathrm{m}), 8.86(1 \mathrm{H}, \mathrm{s}), 9.74(1 \mathrm{H}, \mathrm{m}) ;{ }^{13} \mathrm{C}-\mathrm{NMR}\left(\mathrm{CDCl}_{3}\right) \delta$ : $22.8,23.1,28.2,39.4,41.8,45.6,55.8,115.3,123.7,126.4,126.7,127.5$ 128.4, 129.5, 130.1, 136.0, 144.7, 152.7, 193.5. Anal. Calcd for $\mathrm{C}_{20} \mathrm{H}_{23} \mathrm{~N}_{3} \mathrm{O}$ : C, 74.77; H, 7.17; N, 13.08. Found: C, 74.80; H, 7.20; N, 12.99 .

3-[(6'-Quinolinyl)methylamino]cyclohex-2-en-1-one 16 Compound $15(1 \mathrm{~g}, 4.2 \mathrm{mmol})$ was added to a suspension of sodium hydride $(1 \mathrm{~g}$, $25 \mathrm{mmol}, 60 \%$ in mineral oil) in anhydrous toluene $(50 \mathrm{ml})$. The mixture was refluxed under nitrogen for $2 \mathrm{~h}$ and cooled to room temperature. Methyl iodide $(5 \mathrm{ml}, 80 \mathrm{mmol})$ was then added and the mixture was stirred for $24 \mathrm{~h}$ at $80^{\circ} \mathrm{C}$. After cooling, toluene was washed with water and the insoluble residue in the balloon flask was dissolved in dichloromethane and also washed with water. The organic layers were dried over sodium sulfate and evaporated in vacuo. The crude product was chromatographed on alumina gel with ether and a gradient of methanol as eluent to give $\mathbf{1 6}$ as a yellow powder: $40 \%$, mp $134-136^{\circ} \mathrm{C} .{ }^{1} \mathrm{H}-\mathrm{NMR}\left(\mathrm{CDCl}_{3}\right) \delta: 1.87(2 \mathrm{H}, \mathrm{m}), 2.27$ $(4 \mathrm{H}, \mathrm{m}), 3.30(3 \mathrm{H}, \mathrm{s}), 5.35(1 \mathrm{H}, \mathrm{s}), 7.49(3 \mathrm{H}, \mathrm{m}), 8.12(2 \mathrm{H}, \mathrm{m}), 8.92(1 \mathrm{H}, \mathrm{d}$, $J=3.6 \mathrm{~Hz}) ;{ }^{13} \mathrm{C}-\mathrm{NMR}\left(\mathrm{CDCl}_{3}\right) \delta: 22.3,28.4,35.9,40.6,101.2,121.7,125.0$, 128.3, 128.6, 131.1, 135.6, 143.0, 146.7, 150.8, 164.4, 197.3. Anal. Calcd for $\mathrm{C}_{16} \mathrm{H}_{16} \mathrm{~N}_{2} \mathrm{O}: \mathrm{C}, 76.19 ; \mathrm{H}, 6.35 ; \mathrm{N}, 11.11$. Found: C, 76.27; H, 6.37; N, 11.09 .

3-[(6'-Quinolinyl)ethylamino]cyclohex-2-en-1-one 17 Compound 15 $(1 \mathrm{~g}, 4.2 \mathrm{mmol})$ was added to a suspension of sodium hydride $(1 \mathrm{~g}, 25 \mathrm{mmol}$, $60 \%$ in mineral oil) in anhydrous toluene $(50 \mathrm{ml})$. The mixture was refluxed under nitrogen for $2 \mathrm{~h}$ and cooled to room temperature. Ethyl iodide $(3 \mathrm{ml}$, $38 \mathrm{mmol}$ ) was then added and the mixture was stirred for $24 \mathrm{~h}$ at $80^{\circ} \mathrm{C}$. After cooling, toluene was washed with water and the insoluble residue in the balloon flask was dissolved in dichloromethane and also washed with water. The organic layers were dried over sodium sulfate and evaporated in vacuo. The crude product was chromatographed on alumina gel with dichloromethane and a gradient of methanol as eluent to give $\mathbf{1 7}$ as a yellow oil: $37 \%$. ${ }^{1} \mathrm{H}-\mathrm{NMR}\left(\mathrm{CDCl}_{3}\right) \delta: 1.14(3 \mathrm{H}, \mathrm{t}, J=7.1 \mathrm{~Hz}), 1.82(2 \mathrm{H}, \mathrm{m}), 2.17$ $(2 \mathrm{H}, \mathrm{t}, J=6.1 \mathrm{~Hz}), 2.23(2 \mathrm{H}, \mathrm{t}, J=6.2 \mathrm{~Hz}), 3.66(2 \mathrm{H}, \mathrm{q}, J=7.1 \mathrm{~Hz}), 5.29(\mathrm{~s}$, $1 \mathrm{H}), 7.38(\mathrm{~m}, 2 \mathrm{H}), 7.52(1 \mathrm{H}, \mathrm{d}, J=2.3 \mathrm{~Hz}), 8.1(2 \mathrm{H}, \mathrm{m}), 8.87(1 \mathrm{H}, \mathrm{dd}$, $J=4.2,1.6 \mathrm{~Hz}) ;{ }^{13} \mathrm{C}-\mathrm{NMR}\left(\mathrm{CDCl}_{3}\right) \delta: 12.5,22.8,29.0,36.4,48.0,101.0$, 122.3, 126.7, 128.8, 130.1, 130.7, 136.3, 141.8, 147.3, 151.4, 164.5, 198.0. Anal. Calcd for $\mathrm{C}_{17} \mathrm{H}_{18} \mathrm{~N}_{2} \mathrm{O}: \mathrm{C}, 76.70 ; \mathrm{H}, 6.77 ; \mathrm{N}, 10.53$. Found: $\mathrm{C}, 76.58 ; \mathrm{H}$, $6.77 ; \mathrm{N}, 10.57$.

3-[(6'-Quinolinyl)diethylaminoethylamino]cyclohex-2-en-1-one 18 Compound $15(0.75 \mathrm{~g}, 3.2 \mathrm{mmol})$ was added to a suspension of sodium hydride $(2 \mathrm{~g}, 50 \mathrm{mmol}, 60 \%$ in mineral oil) in anhydrous toluene $(50 \mathrm{ml})$. The mixture was refluxed under nitrogen for $2 \mathrm{~h}$ and cooled to room temperature. Diethylaminoethylchloride hydrochloride $(0.5 \mathrm{~g}, 2.9 \mathrm{mmol})$ was then added and the mixture was refluxed for $2 \mathrm{~h}$. After cooling, toluene was washed with water and the insoluble residue in the balloon flask was dissolved in dichloromethane and also washed with water. The organic layers were dried over sodium sulfate and evaporated in vacuo. The crude product was chromatographed on alumina gel with ether and a gradient of methanol as eluent to give 18 as a yellow oil: $28 \%$. ${ }^{1} \mathrm{H}-\mathrm{NMR}\left(\mathrm{CDCl}_{3}\right) \delta: 0.87(6 \mathrm{H}, \mathrm{t}, J=7.1 \mathrm{~Hz}$, $\left.\mathrm{CH}_{3} 4^{\prime \prime}\right), 1.84(2 \mathrm{H}, \mathrm{m}), 2.21(2 \mathrm{H}, \mathrm{t}, J=6.2 \mathrm{~Hz}), 2.24(2 \mathrm{H}, \mathrm{t}, J=6.3 \mathrm{~Hz}), 2.40$ $(4 \mathrm{H}, \mathrm{q}, J=7.1 \mathrm{~Hz}), 2.63(2 \mathrm{H}, \mathrm{t}, J=7.3 \mathrm{~Hz}), 3.70(2 \mathrm{H}, \mathrm{t}, J=7.1 \mathrm{~Hz}), 5.30(1 \mathrm{H}$ s), $7.38(1 \mathrm{H}, \mathrm{m}), 7.49(1 \mathrm{H}, \mathrm{dd}, J=8.9,2.4 \mathrm{~Hz}), 7.62(1 \mathrm{H}, \mathrm{d}, J=2.2 \mathrm{~Hz}), 8.07$ $(2 \mathrm{H}, \mathrm{m}), 8.87(1 \mathrm{H}, \mathrm{dd}, J=4.2,1.6 \mathrm{~Hz}) ;{ }^{13} \mathrm{C}-\mathrm{NMR}\left(\mathrm{CDCl}_{3}\right) \delta: 12.2(2 \mathrm{C})$ $22.9,29.7,36.4,47.6(2 \mathrm{C}), 50.3,52.0,101.4,122.2,126.6,128.8,130.2$, 131.5, 136.2, 142.6, 147.3, 151.4, 164.7, 197.9. Anal. Calcd for $\mathrm{C}_{21} \mathrm{H}_{27} \mathrm{~N}_{3} \mathrm{O}$ C, 74.78; H, 8.01; N, 12.46. Found: C, 74.84; H, 8.03; N, 12.49 .

3-[(6'-Quinolinyl)dimethylaminopropylamino]cyclohex-2-en-1-one 19 Compound $15(0.5 \mathrm{~g}, 2.1 \mathrm{mmol})$ and dimethylaminopropylchloride hydrochloride $(0.4 \mathrm{~g}, 2.53 \mathrm{mmol})$ were added to a suspension of sodium hydride $(1 \mathrm{~g}, 25 \mathrm{mmol}, 60 \%$ in mineral oil) in dimethylformamide $(10 \mathrm{ml})$. The mixture was refluxed under nitrogen for $3 \mathrm{~h}$ and cooled to room temperature. Then, methanol was added to neutralize sodium hydride excess, followed by water $(30 \mathrm{ml})$. After extraction with dichloromethane $(3 \times 50 \mathrm{ml})$, the organic layers were dried over sodium sulfate and evaporated in vacuo. The crude product was chromatographed on alumina gel with ether and a gradient of methanol as eluent to give $\mathbf{1 9}$ as a yellow oil: $45 \%$. ${ }^{1} \mathrm{H}-\mathrm{NMR}\left(\mathrm{CDCl}_{3}\right) \delta$ : $1.82(2 \mathrm{H}, \mathrm{m}, \mathrm{H} 5), 1.91(2 \mathrm{H}, \mathrm{m}), 2.13(6 \mathrm{H}, \mathrm{s}), 2.27(6 \mathrm{H}, \mathrm{m}), 3.72(2 \mathrm{H}, \mathrm{t}$ $J=7.7 \mathrm{~Hz}), 5.36(1 \mathrm{H}, \mathrm{s}), 7.46(2 \mathrm{H}, \mathrm{m}), 7.59(1 \mathrm{H}, \mathrm{d}, J=2.3 \mathrm{~Hz}), 8.13(2 \mathrm{H}, \mathrm{m})$, $8.94(1 \mathrm{H}, \mathrm{dd}, J=4.2,1.6 \mathrm{~Hz}) ;{ }^{13} \mathrm{C}-\mathrm{NMR}\left(\mathrm{CDCl}_{3}\right) \delta: 22.8,25.4,29.0,36.4$ $45.7,51.4,56.8,101.2,122.2,126.6,128.8,129.9,131.7,136.2,142.0$, 147.2, 151.4, 164.8, 197.8. Anal. Calcd for $\mathrm{C}_{20} \mathrm{H}_{25} \mathrm{~N}_{3} \mathrm{O}: \mathrm{C}, 74.30 ; \mathrm{H}, 7.74$ N, 13.0. Found: C, 74.41; H, 7.73; N, 13.06

7-Methyl-5,6,8,9,10,11-hexahydropyrido[2,3-c]carbazol-11-one 20 Compound $16(0.14 \mathrm{~g}, 0.6 \mathrm{mmol})$ underwent irradiation under different conditions (see Tables 2, 3). Then, the solvents were evaporated under reduced pressure. The crude product was chromatographed on alumina gel using dichloromethane and a gradient of methanol as eluent to give $\mathbf{2 0}$ as a white powder: $22 \%$ (best yield), mp $196-198^{\circ} \mathrm{C} .{ }^{1} \mathrm{H}-\mathrm{NMR}\left(\mathrm{CDCl}_{3}\right) \delta: 2.17(2 \mathrm{H}$, $\mathrm{m}), 2.45(2 \mathrm{H}, \mathrm{t}, J=6 \mathrm{~Hz}), 2.74(2 \mathrm{H}, \mathrm{t}, J=8.3 \mathrm{~Hz}), 2.85(2 \mathrm{H}, \mathrm{t}, J=6.2 \mathrm{~Hz})$ $3.09(2 \mathrm{H}, \mathrm{t}, J=7.8 \mathrm{~Hz}), 3.63(3 \mathrm{H}, \mathrm{s}), 7.08(1 \mathrm{H}, \mathrm{m}), 8.13(1 \mathrm{H}, \mathrm{dd}, J=4.8$, $1.6 \mathrm{~Hz}), 8.79(1 \mathrm{H}, \mathrm{dd}, J=4.2,1.6 \mathrm{~Hz}) ;{ }^{13} \mathrm{C}-\mathrm{NMR}\left(\mathrm{CDCl}_{3}\right) \delta: 20.2,22.7,23.4$ $30.5,32.3,39.4,115.9,117.3,122.6,128.4,132.8,133.5,145.2,145.7$, 154.3, 194.1. Anal. Calcd for $\mathrm{C}_{16} \mathrm{H}_{16} \mathrm{~N}_{2} \mathrm{O}$ : C, 76.19; H, 6.35; N, 11.11 . Found: C, 76.29; H, 6.33; N, 11.15 .

7-Ethyl-5,6,8,9,10,11-hexahydropyrido[2,3-c|carbazol-11-one 21 Compound $17(0.16 \mathrm{~g}, 0.6 \mathrm{mmol})$ underwent irradiation under different conditions (see Tables 2, 3). Then, the solvents were evaporated under reduced pressure. The crude product was chromatographed on alumina gel using dichloromethane as eluent to give $\mathbf{2 1}$ as a yellow oil: $43 \%$ (best yield). ${ }^{1} \mathrm{H}$ NMR $\left(\mathrm{CDCl}_{3}\right) \delta: 1.22(3 \mathrm{H}, \mathrm{t}, J=7.2 \mathrm{~Hz}), 2.08(2 \mathrm{H}, \mathrm{m}), 2.46(2 \mathrm{H}, \mathrm{t}$, $J=6 \mathrm{~Hz}), 2.73(4 \mathrm{H}, \mathrm{m}), 3.09(2 \mathrm{H}, \mathrm{t}, J=7.6 \mathrm{~Hz}), 3.79(2 \mathrm{H}, \mathrm{q}, J=7.2 \mathrm{~Hz}), 7.07$ $(1 \mathrm{H}, \mathrm{m}), 8.13(1 \mathrm{H}, \mathrm{dd}, J=4.9,1.5 \mathrm{~Hz}), 8.85(1 \mathrm{H}, \mathrm{dd}, J=7.8,1.5 \mathrm{~Hz}) ;{ }^{13} \mathrm{C}-$ NMR $\left(\mathrm{CDCl}_{3}\right) \delta: 16.2,20.2,22.5,23.6,32.6,39.1,39.5,116.2,121.0$, 122.6, 128.4, 132.1, 133.5, 145.0, 145.3, 154.4, 194.1. Anal. Calcd for $\mathrm{C}_{17} \mathrm{H}_{18} \mathrm{~N}_{2} \mathrm{O}: \mathrm{C}, 76.69 ; \mathrm{H}, 6.77 ; \mathrm{N}, 10.53$. Found: $\mathrm{C}, 76.75 ; \mathrm{H}, 6.78 ; \mathrm{N}, 10.58$.

7-( $N, N$-Diethylaminoethyl)-5,6,8,9,10,11-hexahydropyrido[2,3-c]carbazol-11-one 22 Compound $18(0.4 \mathrm{~g}, 1.2 \mathrm{mmol})$ underwent irradiation under different conditions (see Tables 2,3). Then, the solvents were evaporated under reduced pressure. The crude product was chromatographed on alumina gel using ether and a gradient of methanol as eluent to give $\mathbf{2 2}$ as a yellow oil: $38 \%$ (best yield). ${ }^{1} \mathrm{H}-\mathrm{NMR}\left(\mathrm{CDCl}_{3}\right) \delta: 0.90(6 \mathrm{H}, \mathrm{t}, J=7.2 \mathrm{~Hz})$, $2.08(2 \mathrm{H}, \mathrm{m}, \mathrm{H9}), 2.47(6 \mathrm{H}, \mathrm{m}), 2.54(2 \mathrm{H}, \mathrm{t}, J=7.1 \mathrm{~Hz}), 2.77(4 \mathrm{H}, \mathrm{m}), 3.09$ $(2 \mathrm{H}, \mathrm{t}, J=7.5 \mathrm{~Hz}), 3.80(2 \mathrm{H}, \mathrm{t}, J=6.9 \mathrm{~Hz}), 7.07(1 \mathrm{H}, \mathrm{m}), 8.13(1 \mathrm{H}, \mathrm{d}$, $J=4.1 \mathrm{~Hz}), 8.84(1 \mathrm{H}, \mathrm{dd}, J=7.9,1.6 \mathrm{~Hz}) ;{ }^{13} \mathrm{C}-\mathrm{NMR}\left(\mathrm{CDCl}_{3}\right) \delta: 12.4(2 \mathrm{C})$, $20.5,22.8,23.6,31.3,39.3,43.8,48.1$ (2C), 53.5, 116.2, 117.4, 122.6, 128.4, 132.6, 133.4, 145.4, 145.5, 154.5, 194.2. Anal. Calcd for $\mathrm{C}_{21} \mathrm{H}_{27} \mathrm{~N}_{3} \mathrm{O}$ : C, 74.78; H, 8.01; N, 12.46. Found: C, 74.90; H, 7.99; N, 12.49 .

7-(N,N-Dimethylaminopropyl)-5,6,8,9,10,11-hexahydropyrido[2,3c) carbazol-11-one 23 Compound $19(0.3 \mathrm{~g}, 0.9 \mathrm{mmol})$ underwent irradiation under different conditions (see Tables 2,3 ). Then, the solvents were evaporated under reduced pressure. The residue couldn't be purified by usual column chromatography techniques, so the proportions of compounds $\mathbf{2 7}$ and $\mathbf{2 3}$ in the mixture (orange oil) were deduced from proton integrations in ${ }^{1} \mathrm{H}-\mathrm{NMR}$ spectrum. Best yield: $32 \% .{ }^{1} \mathrm{H}-\mathrm{NMR}\left(\mathrm{CDCl}_{3}\right) \delta$ : $1.71(2 \mathrm{H}, \mathrm{m})$, $2.06(2 \mathrm{H}, \mathrm{m}), 2.13(6 \mathrm{H}, \mathrm{s}), 2.17(2 \mathrm{H}, \mathrm{t}, J=6.7 \mathrm{~Hz}), 2.45(2 \mathrm{H}, \mathrm{t}, J=6 \mathrm{~Hz})$ $2.74(4 \mathrm{H}, \mathrm{m}), 3.06(2 \mathrm{H}, \mathrm{t}, J=7.5 \mathrm{~Hz}), 3.80(2 \mathrm{H}, \mathrm{t}, J=7.5 \mathrm{~Hz}), 7.06(1 \mathrm{H}, \mathrm{m})$, $8.11(1 \mathrm{H}$, dd $J=4.9,1.7 \mathrm{~Hz}), 8.84(1 \mathrm{H}, \mathrm{dd}, J=7.8,1.7 \mathrm{~Hz}) ;{ }^{13} \mathrm{C}-\mathrm{NMR}$ $\left(\mathrm{CDCl}_{3}\right) \delta: 20.4,22.7,23.7,28.7,32.7,39.4,42.1,45.7$ (2C), 56.3, 116.1, $117.4,122.5,128.4,132.6,133.5,145.4,145.6,154.5,194.2$

7-Methyl-8,9,10,11-tetrahydropyrido[2,3-c]carbazol-11-one 
Method 1: Compound 20 (70 $\mathrm{mg}, 0.3 \mathrm{mmol})$ was added to a supension of $\mathrm{Pd} /$ carbon $10 \%(100 \mathrm{mg})$ in diphenylether $(20 \mathrm{ml})$ and the reaction mixture was refluxed under nitrogen for $2 \mathrm{~h}$. Still hot, the reaction mixture was filtered in order to eliminate $\mathrm{Pd} / \mathrm{Carbon}$, which was washed with a hot mixture of dichloromethane and methanol (50/50). Dichloromethane and methanol were evaporated in vacuo and the diphenylether containing the final product was chromatographed on silica gel using dichloromethane as eluent to eliminate diphenylether and dichloromethane and a gradient of methanol to give 24 as a yellow powder: $30 \%, \mathrm{mp} 214-216^{\circ} \mathrm{C}$

Method 2: Compound $16(0.14 \mathrm{~g}, 0.6 \mathrm{mmol})$ underwent irradiation under different conditions (see Tables 2,3). Then, the solvents were evaporated under reduced pressure. The crude product was chromatographed on alumina gel using dichloromethane and a gradient of methanol as eluent to give 24 as a yellow powder: $30 \%$ (best yield), mp $214-216^{\circ} \mathrm{C} .{ }^{1} \mathrm{H}-\mathrm{NMR}$ $\left(\mathrm{CDCl}_{3}\right) \delta: 2.10(2 \mathrm{H}, \mathrm{m}), 2.54(2 \mathrm{H}, \mathrm{t}, J=6.0 \mathrm{~Hz}), 2.67(2 \mathrm{H}, \mathrm{t}, J=6.0 \mathrm{~Hz})$ $3.41(3 \mathrm{H}, \mathrm{s}), 7.22(1 \mathrm{H}, \mathrm{m}), 7.39(1 \mathrm{H}, \mathrm{d}, J=9 \mathrm{~Hz}), 7.80(1 \mathrm{H}, \mathrm{d}, J=9 \mathrm{~Hz}), 8.78$ $(1 \mathrm{H}, \mathrm{dd}, J=4.3,1.6 \mathrm{~Hz}), 10.22(\mathrm{dd}, 1 \mathrm{H}, J=8.5,1.6 \mathrm{~Hz}):{ }^{13} \mathrm{C}-\mathrm{NMR}\left(\mathrm{CDCl}_{3}\right)$ $\delta: 22.9,23.1,30.3,39.3,113.7,115.9,119.2,120.9,123.6,125.8,133.9$, 137.1, 146.2, 148.4, 151.2, 193.5. Anal. Calcd for $\mathrm{C}_{16} \mathrm{H}_{14} \mathrm{~N}_{2} \mathrm{O}: \mathrm{C}, 76.80 ; \mathrm{H}$ 5.60; N, 11.20. Found: C, 76.84; H, 5.61; N, 11.24.

7-Ethyl-8,9,10,11-tetrahydropyrido[2,3-c]carbazol-11-one 25 Method 1: Compound $21(80 \mathrm{mg}, 0.3 \mathrm{mmol})$ was added to a suspension of $\mathrm{Pd} /$ carbon $10 \%(100 \mathrm{mg})$ in diphenylether $(20 \mathrm{ml})$ and the reaction mixture was refluxed under nitrogen for $2 \mathrm{~h}$. Still hot, the reaction mixture was filtered in order to eliminate $\mathrm{Pd} /$ Carbon, which was washed with a hot mixture of dichloromethane and methanol (50/50). Dichloromethane and methanol were evaporated in vacuo and the diphenylether containing the final product was chromatographed on silica gel using dichloromethane as eluent to eliminate diphenylether and dichloromethane and a gradient of methanol to give 25 as an orange oil: $30 \%$.

Method 2: Compound $17(0.16 \mathrm{~g}, 0.6 \mathrm{mmol})$ underwent irradiation under different conditions (see Tables 2,3). Then, the solvents were evaporated under reduced pressure. The crude product was chromatographed on alumina gel using dichloromethane as eluent to give $\mathbf{2 5}$ as an orange oil: $\mathbf{3 8 \%}$ (best yield). ${ }^{1} \mathrm{H}-\mathrm{NMR} \delta: 1.37(3 \mathrm{H}, \mathrm{t}, J=7.4 \mathrm{~Hz}), 2.22(2 \mathrm{H}, \mathrm{m}), 2.63(2 \mathrm{H}, \mathrm{t}$ $J=6.4 \mathrm{~Hz}), 2.93(2 \mathrm{H}, \mathrm{t}, J=6.2 \mathrm{~Hz}), 4.17(2 \mathrm{H}, \mathrm{q}, J=7.4 \mathrm{~Hz}), 7.45(1 \mathrm{H}, \mathrm{m})$, $7.63(\mathrm{~d} 1 \mathrm{H}, J=9.1 \mathrm{~Hz}), 7.93(1 \mathrm{H}, \mathrm{d}, J=9 \mathrm{~Hz}), 8.79(1 \mathrm{H}, \mathrm{dd}, J=4.4,1.8 \mathrm{~Hz})$ $10.31(1 \mathrm{H}, \mathrm{dd}, J=8.5,1.8 \mathrm{~Hz}) ;{ }^{13} \mathrm{C}-\mathrm{NMR}\left(\mathrm{CDCl}_{3}\right) \delta: 15.6,23.0,23.4,39.1$, $39.5,113.9,116.3,120.7,121.0,124.6,126.0,133.2,137.4,146.1,148.2$, 150.5, 193.6. Anal. Calcd for $\mathrm{C}_{17} \mathrm{H}_{16} \mathrm{~N}_{2} \mathrm{O}: \mathrm{C}, 77.27 ; \mathrm{H}, 6.06 ; \mathrm{N}, 10.61$. Found: C, 77.36; H, 6.09; N, 10.58.

7-(N,N-Diethylaminoethyl)-8,9,10,11-tetrahydropyrido[2,3-c]carbazol11-one 26 Compound $18(0.4 \mathrm{~g}, 1.2 \mathrm{mmol})$ underwent irradiation under different conditions (see Tables 2, 3). Then, the solvents were evaporated under reduced pressure. The crude product was chromatographed on alumina gel using ether and a gradient of methanol as eluent to give $\mathbf{2 6}$ as a yellow oil: $23 \%$ (best yield). ${ }^{1} \mathrm{H}-\mathrm{NMR}\left(\mathrm{CDCl}_{3}\right) \delta$ : $0.85(6 \mathrm{H}, \mathrm{t}, J=7.2 \mathrm{~Hz}), 2.19$ $(2 \mathrm{H}, \mathrm{m}), 2.46(4 \mathrm{H}, \mathrm{q}, J=7.2 \mathrm{~Hz}), 2.63(2 \mathrm{H}, \mathrm{t}, J=6.3 \mathrm{~Hz}), 2.69(2 \mathrm{H}, \mathrm{t}$, $J=6.1 \mathrm{~Hz}), 2.98(2 \mathrm{H}, \mathrm{t}, J=6.3 \mathrm{~Hz}), 4.14(2 \mathrm{H}, \mathrm{t}, J=6.1 \mathrm{~Hz}), 7.43(1 \mathrm{H}, \mathrm{m})$, $7.60(1 \mathrm{H}, \mathrm{d}, J=9.1 \mathrm{~Hz}), 7.89(1 \mathrm{H}, \mathrm{d}, J=9.1 \mathrm{~Hz}), 8.79(1 \mathrm{H}, \mathrm{dd}, J=4.1$, $1.6 \mathrm{~Hz}), 10.30(1 \mathrm{H}, \mathrm{dd}, J=8.5,1.6 \mathrm{~Hz}) ;{ }^{13} \mathrm{C}-\mathrm{NMR}\left(\mathrm{CDCl}_{3}\right) \delta: 11.3,23.4$ (2C), 39.4, 43.8, 48.2 (2C), 53.0, 113.9, 116.2, 120.7, 121.0, 124.5, 126.2, 133.5, 137.1, 146.4, 148.5, 151.6, 193.7. Anal. Calcd for $\mathrm{C}_{21} \mathrm{H}_{25} \mathrm{~N}_{3} \mathrm{O}: \mathrm{C}$, 75.22; H, 7.46; N, 12.54. Found: C, 75.28; H, 7.47; N, 12.49 .

7-( $N, N$-Dimethylaminopropyl)-8,9,10,11-tetrahydropyrido[2,3-c]carbazol-11-one 27 Compound $19(0.3 \mathrm{~g}, 0.9 \mathrm{mmol})$ underwent irradiation under different conditions (see Tables 2,3). Then, the solvents were evaporated under reduced pressure. The residue couldn't be purified by usual column chromatography techniques, so the proportions of compounds 27 and 23 in the mixture (orange oil) were deduced from proton integrations in ${ }^{1} \mathrm{H}-$ NMR spectrum. Best yield: 45\%. ${ }^{1} \mathrm{H}-\mathrm{NMR}\left(\mathrm{CDCl}_{3}\right) \delta: 1.99(2 \mathrm{H}, \mathrm{m}), 2.30$ $(10 \mathrm{H}, \mathrm{m}), 2.72(2 \mathrm{H}, \mathrm{t}, J=5.7 \mathrm{~Hz}), 3.07(2 \mathrm{H}, \mathrm{t}, J=6.2 \mathrm{~Hz}), 4.31(2 \mathrm{H}, \mathrm{t}$, $J=7.0 \mathrm{~Hz}), 7.52(1 \mathrm{H}, \mathrm{m}), 7.80(1 \mathrm{H}, \mathrm{d}, J=9.1 \mathrm{~Hz}), 7.99(1 \mathrm{H}, \mathrm{d}, J=9 \mathrm{~Hz}), 8.88$ $(1 \mathrm{H}, \mathrm{dd}, J=4.1,1.6 \mathrm{~Hz}), 10.38(1 \mathrm{H}, \mathrm{dd}, J=8.5,1.6 \mathrm{~Hz}) ;{ }^{13} \mathrm{C}-\mathrm{NMR}\left(\mathrm{CDCl}_{3}\right)$ $\delta: 23.2,23.5,28.2,39.6,41.9,45.8(2 \mathrm{C}), 56.1,114.2,116.3,120.6,121.0$, $124.5,126.3,133.8,137.1,146.5,148.6,151.2,194.2$.

7H-8,9,10,11-Tetrahydropyrido[2,3-c] carbazol-11-one 38 Compound $37(50 \mathrm{mg}, 0.21 \mathrm{mmol})$ was added to a suspension of $\mathrm{Pd} /$ carbon $10 \%$ $(100 \mathrm{mg})$ in diphenylether $(20 \mathrm{ml})$ and the reaction mixture was refluxed under nitrogen for $2 \mathrm{~h}$. Still hot, the reaction mixture was filtered in order to eliminate $\mathrm{Pd} /$ Carbon, which was washed with a hot mixture of dichloromethane and methanol (50/50). Dichloromethane and methanol were evaporated in vacuo and the diphenylether containing the final product was chromatographed on silica gel using dichloromethane as eluent to elimi- nate diphenylether and dichloromethane and a gradient of methanol to give 38 as a white powder: $30 \%, \mathrm{mp} 223-225^{\circ} \mathrm{C} .{ }^{1} \mathrm{H}-\mathrm{NMR}\left(\mathrm{CDCl}_{3}\right) \delta: 2.24$ $(2 \mathrm{H}, \mathrm{m}), 2.69(2 \mathrm{H}, \mathrm{t}, J=7.1 \mathrm{~Hz}), 3.03(2 \mathrm{H}, \mathrm{t}, J=6.3 \mathrm{~Hz}), 7.53(1 \mathrm{H}, \mathrm{m}), 7.69$ $(1 \mathrm{H}, \mathrm{d}, J=8.9 \mathrm{~Hz}), 7.87(1 \mathrm{H}, \mathrm{d}, J=9 \mathrm{~Hz}), 8.79(1 \mathrm{H}, \mathrm{dd}, J=4.2,1.6 \mathrm{~Hz})$ $10.33(1 \mathrm{H}, \mathrm{d}, J=8.5 \mathrm{~Hz}) ;{ }^{13} \mathrm{C}-\mathrm{NMR}\left(\mathrm{CDCl}_{3}\right) \delta: 23.4,23.8,39.2,116.0$ 116.3, 118.9, 119.9, 123.2, 128.2, 132.8, 137.4, 145.2, 147.1, 151.4, 194.1. Anal. Calcd for $\mathrm{C}_{15} \mathrm{H}_{12} \mathrm{~N}_{2} \mathrm{O}: \mathrm{C}, 76.27 ; \mathrm{H}, 5.08 ; \mathrm{N}, 11.86$. Found: $\mathrm{C}, 76.32 ; \mathrm{H}$, 5.07; N, 11.91 .

Biological Assay Doxorubicin hydrochloride (Pharmacia, St-Quentin en Yvelines, France), RPMI 1640 medium and fetal calf serum (Polylabo, Paris, France) were used in this study. 3-(4,5-dimethylthiazol-2-yl)-2,5diphenyltetrazolium bromide (MTT) was provided by Sigma (St-Quentin Fallavier, France). All other reagents were of analytical grade and were obtained from commercial sources.

Cells and Culture: The human leukemic cell line K 562 was obtained from the American type culture collection (Rockville, MD, U.S.A.). The human ovarian carcinoma cell line A 2780 was generously given by Dr. P Canal (Centre Claudius Régaud, Toulouse). The doxorubicin resistant cell line A $2780 \mathrm{R}$ was established by the continuous exposure of cells to gradually increasing concentrations of doxorubicin and was maintained in a medium supplemented with doxorubicin at $0.1 \mu \mathrm{g} / \mathrm{ml}$. The MDR phenotype expression of A $2780 \mathrm{R}$ cell lines was assessed by an immunohistochemistry method, using the two P-glycoprotein specific murine monoclonal antibody C219 (Cantocor, Malvern, PA, U.S.A.) and JSB1 (Tebu, Le Perray en Yvelines, France). Cultures were grown in RPMI 1460 medium supplemented with $10 \%$ fetal calf serum, antibiotics and glutamine at $37^{\circ} \mathrm{C}$ in a humidified atmosphere containing $5 \% \mathrm{CO}_{2}$

Cytotoxicity Assay: In all the experiments, K 562 and A 2780 cells were seeded at a final density of 5000 cells/well in 96 well microtiter plates and were treated with drugs (doxorubicin and compounds 11, 12, 13, 20, 21, 22 37, 38 and 39). Seven dilutions were used for each drug. After $96 \mathrm{~h}$ of incubation, $10 \mu \mathrm{l}$ of MTT solution in PBS $(5 \mathrm{mg} / \mathrm{ml}$, phosphate-buffer saline $\mathrm{pH}$ 7.3) were added to each well and the wells were exposed to $37^{\circ} \mathrm{C}$ for $4 \mathrm{~h}$ This colorimetric assay is based on the ability of live and metabolically unimpaired tumor-cell targets to reduce MTT to a blue formazan product. Then, $100 \mu \mathrm{l}$ of a mixture of isopropanol and $1 \mathrm{~m}$ hydrochloric acid (96/4, $\mathrm{v} / \mathrm{v}$ ) were added to each well. After $10 \mathrm{~min}$ of vigourous shaking so as to solubilize formazan crystals, the absorbance was measured on a microculture plate reader (Dynatech MR 5000, France) at $570 \mathrm{~nm}$. For each assay, at least three experiments were performed in triplicate. The resistance factor was calculated from the ratio between the $\mathrm{IC}_{50} \%$ growth-inhibitory concentrations ( $\mathrm{IC}_{50}$ values) recorded from A $2780 \mathrm{R}$ and A $2780 \mathrm{~S}$ cells, respectively, for the following tested drugs: doxorubicin, compounds 11, 12, 13, 20, 21, $22,37,38$ and 39 .

\section{References}

1) Delvaux E., J. Pharm. Belg., 13, 955-959 (1931).

2) Wright C., Addae-Kyereme J., Breen A. G., Brown J. E., Cox M. F., Croft S. L., Gokçek Y., Kendrick H., Philips R. M., Pollet P. L., J. Med. Chem., 44, 3187-3194 (2001).

3) Paulo A., Pimentel M., Viegas S., Pires I., Duarte A., Cabrita J., Gomes E., J. Ethnopharmacol., 44, 73 -77 (1994).

4) Arzel E., Rocca P., Grellier P., Labaeïd M., Frappier F., Guéritte F., Gaspard C., Marsais F., Godard A., Quéguiner G., J. Med. Chem., 44, $949-960$ (2001).

5) Bonjean K., De Pauw-Gillet M. C., Defresne M. P., Colson P., Houssier C., Dassonneville L., Bailly C., Greimers R., Wright C., Quetin-Leclercq J., Tits M., Angenot L., Biochemistry, 37, 51365146 (1998).

6) Goodwin S., Smith A. F., Horning E. C., J. Am. Chem. Soc., 81, 1903-1908 (1959)

7) Chu Y., Hsu M. T., Nucleic Acids Res., 20, 4033- 4038 (1992).

8) Monnot M., Mauffret O., Simon V., Lescot E., Psaume B., Saucier J. M., Charra M., Belehradek J., Fermandjian S., J. Biol. Chem., 25, $1820-1829$ (1991).

9) Stiborova M., Bieler C. A., Wiessler M., Frei E., Biochem. Pharmacol., 62, 1675-1684 (2001).

10) Ohashi M., Oki T., Expert Opin. Ther. Pat., 6, 1285-1294 (1996).

11) Yang S.-W., Abdel-Kader M., Malone S., Werkhoven M. C. M., Wisse J. H., Bursuker I., Neddermann K., Fairchild C., Raventos-Suarez C., Menendez A. T., Lane K., Kingston D. G. I., J. Nat. Prod., 62, 976983 (1999)

12) Schonafinger K., Yasenchak C. M., Vollman A., Ong H. H., J. Heterocycl. Chem., 25, 535-537 (1988). 
13) Mouddib A., Joseph B., Hasnaoui A., Merour J. Y., Synthesis, 4, 549556 (2000).

14) Archer S., Ross B. S., Pica-Mattoccia L., Cioli D., J. Med. Chem., 30, 1204-1210 (1987).

15) Karmakar A. C., Gandhi K. K., Jayanta K. R., J. Chem. Soc. Perkin Trans. 1, 1991, 1997-2002 (1991).

16) Perche J. C., Saint-Ruf G., Buu-Hoï N. P., J. Chem. Soc. Perkin Trans. $1,1972,260-262$ (1972).

17) Moinet-Hedin V., Tabka T., Poulain L., Godard T., Lechevrel M., Saturnino C., Lancelot J. C., Le Talaër J. Y., Gauduchon P., Anti-Cancer Drug Design, 15, 109-118 (2000).

18) Aragon P. J., Yapi A. D., Pinguet F., Chezal J. M., Teulade J. C., Chapat J. P., Blache Y., Chem. Pharm. Bull., 52, 659-663 (2004).

19) Desbois N., Chezal J. M., Fauvelle F., Debouzy J. C., Lartigue C., Blache Y., Moreau E., Madelmont J. C., Chavignon O., Teulade J. C., Heterocycles, 65, 1122-1138 (2005).

20) Ouali M., Missoum A., Sinibaldi-Troin M. E., Gramain J. C., Synthetic Commun., 26, 657-670 (1996).

21) Blache Y., Sinibaldi-Troin M. E., Hichour M., Benezech V., Chavignon O., Gramain J. C., Teulade J. C., Chapat J. P., Tetrahedron, 55, 1959-1970 (1999).

22) Blache Y., Sinibaldi-Troin M. E., Voldoire A., Chavignon O., Gramain J. C., Teulade J. C., Chapat J. P., J. Org. Chem., 62, 8553-8556 (1997).

23) Blache Y., Chavignon O., Sinibaldi-Troin M. E., Gueiffier A., Teulade J. C., Troin Y., Gramain J. C., Heterocycles, 38, 1241-1246 (1994).

24) For a review on the photochemistry of enaminones, see: Aragon P. J., Blache Y., Trends Heterocycl. Chem., 9, 47-59 (2003).

25) Blache Y., Benezech V., Chezal J. M., Boule P., Viols H., Chavignon O., Teulade J. C., Chapat J. P., Heterocycles, 53, 905-916 (2000).

26) Compound 39: (7H)-8,9,10,11-tetrahydroindolo[2,3-c] quinolin-11- one. For preparation see; Aragon P. J., Chezal J. M., Chavignon O., Teulade J. C., Blache Y., Heterocycles, 60, 551-561 (2003).

27) Vlachou M., Andrew T., Loyd R. K., David E. T., Heterocycles, 57, 129-133 (2002).

28) Langedoen A., Koomen G., Pandit U. K., Tetrahedron, 44, 36273631 (1988).

29) Abiberges D., Armand J. P., Chabot G., Bruno R., Bissery M. C., Bayssas M., Klink-Alakl M., Clavel M., Catimel G., Anti-Cancer Drugs, 7, 166-174 (1996).

30) Janin Y. L., Carrez D., Riou J. F., Bisagni E., Chem. Pharm. Bull., 42, 892-895 (1994).

31) Djuric Z., Everett C. K., Valeriote F. A., Cancer Res., 52, 1515-1519 (1992).

32) Yang N. C., Chiang W. L., langan J. R., Tetrahedron Lett., 25, 28552858 (1984).

33) Grellmann K. H., Sherman G. M., Linschitz H., J. Am. Chem. Soc., 86, 303-304 (1964).

34) Chapman O. L., Eian G. L., J. Am. Chem. Soc., 90, 5329 (1968).

35) Grellmann K. H., Schmitt U., J. Am. Chem. Soc., 104, 6267-6273 (1982).

36) Marshall J. A., Acc. Chem. Res., 2, 33-40 (1969).

37) Fujita S., Nômi T., Nozaki H., Tetrahedron Lett., 40, 3557-3558 (1969).

38) Sauers R. R., Schinski W., Mason M. M., Tetrahedron Lett., 47, 4763-4765 (1967).

39) Shanmugasundaram K., Rajenda Prasad K. J., Heterocycles, 51, 2161-2169 (1999).

40) Dupuy M., Pinguet F., Chavignon O., Chezal J. M., Teulade J. C., Chapat J. P., Blache Y., Chem. Pharm. Bull., 49, 1061-1065 (2001).

41) Dupuy M., Blache Y., Bailly C., Poujol S., Chapat J. P., Pinguet F., Anticancer Res., 22, 3365-3372 (2002). 